\title{
FAKTOR-FAKTOR YANG BERHUBUNGAN DENGAN PENGETAHUAN IBU TENTANG TANDA-TANDA BAHAYA KEHAMILAN DI PUSKESMAS GIRI MAYA PANGKAL PINANG
}

\author{
Martina Astari \\ Akademi Kebidanan Bunga Bangsaku \\ Pangkal Pinang
}

Informasi Artikel :

Diterima : April 2019

Disetujui : $\quad$ Juni 2019

"Korespondensi Penulis : martinaastari89@gmail.com

\section{A B S T R A K}

Data World Health Organizationmenurut WHO (2015) diperkirakan 830 perempuan meninggal setiap harinya akbiat komplikasi kehamilan dan proses kelahiran, tercatat ada 303 per 100.000 kelahiran hidup Ibu meninggal selama masa kehamilan.Tujuan penelitian ini untuk diketahui faktor - faktor yang berhubungan dengan pengetahuan Ibu tentang tanda tanda bahaya kehamilan trimester III. Desain penelitian ini menggunakan metode survey analitik dengan pendekatan cross sectional. Jenis pengambilan sampel pada penelitian ini menggunakan teknik accidental sampling. Sampel dalam penelitian ini adalah sebagian Ibu hamil trimester III yang melakukan pemeriksaan kehamilannya di Puskesmas Giri Maya Pangkalpinang Tahun 2017 berjumlah 30 orang. Hasil uji statistik chi square didaptkan $p$ value $0,009 \leq \alpha 0,05$ maka ada hubungan bermakna antara pendidikan Ibu dengan pengetahuan Ibu tentang tanda bahaya kehamilan trimester III. $p$ value $0,013 \leq \alpha 0,05$ maka ada hubungan antara usia Ibu dengan tanda bahaya kehamilan trimester III. $p$ value $0,024 \leq \alpha$ 0,05 maka ada hubungan antara paritas Ibu dengan tanda bahaya kehamilan trimester III di Puskesmas Giri Maya Pangkalpinang Tahun 2017.

Kata Kunci : Pendidikan, Usia, Paritas, Pengetahuan tanda - tanda bahaya Trimester III

\begin{abstract}
According to the World Health Organization data, according to WHO (2015) an estimated 830 women were taken every day due to complications and birth process, considering there were 303 per 100,000 live births. . The design of this study used an analytical survey method using cross sectional. The type of sampling in this study uses accidental sampling technique. The sample in this study was that part of the third trimester pregnant women who performed their pregnancy examinations at the Giri Maya Pangkalpinang Health Center in 2017 received 30 people. The chi square statistical test results obtained $p$ value $0.009 \alpha \alpha$ 0.05 , then there is a relationship between maternal education and maternal knowledge about the danger signs of third trimester pregnancy. $p$ value of $0.013 \alpha \alpha 0.05$, then there is a relationship between the age of the mother and the danger signs of trimester III pregnancy. $p$ value 0.024 $\alpha \alpha 0.05$, then there is a relationship between parity of mothers with trimester III danger signs in Giri Maya Pangkalpinang Health Center 2017.

Keywords: Education, Age, Parity, Knowledge of danger signs Trimester
\end{abstract} III 


\section{PENDAHULUAN}

Kehamilan di Definisikan sebagai fertilisasi atau penyatuan dari spermatozoa dan ovum dan dilanjutkan dengan nidasi atau implantasi. Kehamilan normal akan berlangsung dalam waktu 40 minggu (Prawirohardjo,2016).

Berdasarkan Data World Health Organization (WHO,2015) memperkirakan 830 perempuan meninggal setiap harinya akibat komplikasi kehamilan dan proses kelahiran. Dari data yang tercatat ada 303 per 100.000 kelahiran hidup Ibu meninggal selama masa kehamilan

Menurut data Survei Demografi Kesehatan Indonesia (SDKI,2016) angka kematian Ibu (AKI) dan angka kematian Bayi (AKB) merupakan salah satu indikator pembangunan kesehatan dalam RPJM 2015 2019 dan Sustainable Develoment Goal's (SDGs). Angka Kematian Ibu adalah 359/100.00 kelahiran hidup masih dibawah target SDGs Tahun 2030 yaitu 70/100.00 Kelahiran hidup.

Angka kematian Ibu (AKI) adalah indikator dibidang kesehatan obstetri. Sekitar 800 wanita meninggal setiap harinya dengan penyebab yang berkaitan dengan kehamilan dan persalinan. Hampir seluruh kematian maternal terjadi di negara berkembang dengan tingkat mortalitas yang lebih tinggi di area pedesaan dan komunitas miskin dan berpendidikan rendah (Manuaba,2012).

Penyebab kematian Ibu terbesar yaitu perdarahan $(30,1 \%)$, hipertensi dalam kehamilan $(29,9 \%)$, infeksi (5,5\%), partus lama/macet $(1,8 \%)$, abortus $(1,6 \%)$ dan lain - lain $(34,5 \%)$.

Beberapa keadaan yang menyebabkan kondisi Ibu hamil menjadi beresiko dan mengalami komplikasi selama kehamilan dan persalinan antara lain adalah Ibu hamil yang terlalu muda $<20$ tahun, dan terlalu tua $>35$ tahun, terlalu dekat jarak kelahiran, terlalu banyak anak, pengetahuan Ibu yang kurang dan dapat juga dikarenakan adanya hipertensi, anemia, diabetes (Kemenkes RI,2015).

Angka kematian Ibu di Provinsi Kepulauan Bangka Belitung Tahun 2015 sebanyak 31 orang, mengalami peningkatan dari tahun 2014 sebanyak 28 orang. Penyebab langsung kematian Ibu adalah perdarahan, eklampsia, infeki dan lain - lain. Hal ini terjadi dikarenakan deteksi faktor resiko Ibu hamil dan kunjungan Ibu hamil yang kurang maksimal (Profil Kesehatan Provinsi Bangka Belitung, 2016).

Program pemerintah dalam menurunkan AKI dan AKB yaitu dengan mencanangkan making pregnancy safer atau MPS yang bertujuan untuk menurunkan kematian Ibu, bayi baru lahir, balita dengan upaya seperti penempatan bidan desa, pemberdayaan keluarga dan masyarakat dengan menggunakan Buku kesehatan Ibu dan Anak (KIA) dan program perencanaan persalinan dan pencegahan komplikasi (P4K) serta penyediaan fasilitas kesehatan pelayanan obstetric neonatal emergency dasar (PONED) di puskesmas, perawatan dan pelayanan obstetri neonatal emergency komprehensif (PONEK) (Prawirohardjo,2013).

Cakupan Kunjungan Ibu Hamil (K4) adalah cakupan Ibu hamil yang telah memperoleh pelayanan antenatal sesuai dengan standar, paling sedikit empat kali dengan distribusi waktu 1 kali pada trimester ke1, 1 kali pada trimester ke 2 dan 2 kali pada trimester ke 3 disuatu kerja pada kurun waktu tertentu. Cakupan K4 Provinsi Bangka Belitung yaitu 92,35\% mengalami peningkatan dibandingkan tahun sebelumnya $90,04 \%$. Persentase cakupan kunjungan Ibu hamil tertinggi terdapat di kota pangkalpinang $(94,74 \%)$ dan cakupan terendah dikota belitung $(87,40 \%)$. Hal ini desebabkan karena kunjungan pertama Ibu hamil ke tenaga kesehatan dimulai pada triwulan kedua atau triwulan ketiga kehamilan sehingga cakupan kunjungan ibu hamil K4 tidak tercapai (Profil Kesehatan Provinsi Bangka Belitung,2016).

Tujuan Konseling K4 adalah menjaga agar Ibu sehat selama kehamilan, persalinan, dan nifas serta mengusahakan bayi yang dilahirkan sehat, memantau kemungkinan adanya resiko kehamilan, dan merencanakan penatalaksanaan yang optimal terhadap kehamilan resiko tinggi.

Menurut data Puskesmas Giri Maya Pangkalpinang cakupan ibu hamil dengan resiko kehamilan trimester III pada tahun 2014 sebesar $(88,7 \%)$ responden, tahun 2015 sebesar $(89,4 \%)$ responden dan pada tahun 2016 sebesar $(94,6 \%)$ responden. 
Tanda bahaya kehamilan adalah adanya bahaya atau suatu keadaan yang dapat mempengaruhi keadaan Ibu hamil maupun bayi yang terjadi selama kehamilan atau periode antenatal, yang apabila tidak terdeteksi bisa menyebabkan kematian Ibu maupun bayi yang berada dalam kandungan Ibu. Tanda - tanda bahaya kehamilan Ibu hamil seperti, perdarahan pervaginam, sakit kepala yang hebat dan menetap, pandangan kabur, nyeri abdomen yang hebat, bengkak pada muka atau tangan, janin kurang bergerak, ketuban pecah sebelum waktunya. Pengetahuan dan persiapan yang harus dilakukan Ibu hamil yaitu mengenali tanda - tanda bahaya dan melaksananakan persiapan menghadapi komplikasi (Nugroho,2014).

Berdasarkan penelitian yang dilakukan Ika Desi $\mathrm{H}$ menunjukkan bahwa Ibu hamil dengan yang berpendidikan tinggi ditemukan sebanyak 30 orang $(60 \%)$, dan menunjukkan karakteristik usia, sebagian besar Ibu hamil memiliki usia yang tidak beresiko (20 -35 tahun) sebanyak 41 orang $(82 \%)$. Ibu hamil dengan paritas rendah sebanyak 30 orang $(60 \%)$.

Berdasarkan latar belakang diatas maka penulis tertarik untuk melakukan penelitian yang berjudul "Faktor - faktor yang berhubungan dengan pengetahuan Ibu tentang tanda - tanda bahaya kehamilan trimester III di Puskesmas Giri Maya Pangkalpinang".

\section{METODE PENELITIAN}

Penelitian ini menggunakan metode survey analitik dengan pendekatan cross sectional dimana variabel independen (pendidikan, usia, dan paritas) dan variabel dependen ( pengetahuan ibu tentang tanda tanda bahaya kehamilan Trimester III ).

\section{HASIL PENELITIAN}

\section{Analisis Data}

\section{a. Analisis Univariat}

Data tentang distribusi frekuensi semua variable independent (Pendidikan, usia, dan paritas) dan variable dependent (pengetahuan Ibu tentang tanda bahaya kehamilan Trimester III di Puskemas Giri Maya Pangkalpinang Tahun 2017) yang dianalisis dengan menggunakan table distribusi frekuensi.
1) Pengetahuan Ibu tentang Tanda Bahaya Kehamilan Trimester III

Tabel 1 Distribusi Frekuensi Berdasarkan Pengetahuan Ibu tentang Tanda Bahaya Kehamilan Trimester III di Puskesmas Giri Maya Pangkalpinang Tahun 2017

\begin{tabular}{cccc}
\hline No & Pengetahuan & n & $\begin{array}{c}\text { Persentase } \\
(\boldsymbol{\%})\end{array}$ \\
\hline 1 & Kurang & 12 & 40 \\
\hline 2 & Baik & 18 & 60 \\
\hline & Jumlah & 30 & 100 \\
\hline
\end{tabular}

Berdasarkan tabel 1 bahwa dari 30 responden Ibu Hamil, didapatkan $18 \mathrm{Ibu}$ hamil yang berpengetahuan baik 18 responden $(60 \%)$ lebih besar dibandingkan pengetahuan kurang baik yaitu 12 responden (40\%).

2) Pendidikan

Tabel 2 Distribusi Frekuensi Berdasarkan Pendidikan di Puskesmas Giri Maya Pangkalpinang Tahun 2017

No Pendidikan n Persentase

\begin{tabular}{cccc} 
& & & $(\mathbf{\%})$ \\
\hline 1 & Rendah & 11 & 36,7 \\
\hline 2 & Tinggi & 19 & 63,3 \\
\hline & Jumlah & 30 & 100 \\
\hline
\end{tabular}

Berdasarkan tabel 2 di atas dari 30 reponden yang memiliki Pendidikan tinggi sebanyak 19 orang $(63,3 \%)$ lebih besar jika dibandingkan dengan responden pendidikan rendah sebanyak 11 orang $(43,3 \%)$ sebanyak 133orang $(56,4 \%)$.

3) Usia

Pada penelitian ini responden usia dikelompokkan menjadi 2 kategori yaitu usia yang beresiko tinggi ( jika usia Ibu $<20$ tahun atau $>35$ tahun) dan usia yang beresiko rendah (jika Usia Ibu 20 - 30 tahun). Untuk lebih jelas dilihat pada tabel 3 dibawah ini.

Tabel 3 Distribusi Frekuensi Berdasarkan Usia di Puskesmas Giri Maya Pangkalpinang Tahun 2017

\begin{tabular}{|c|c|c|c|}
\hline No & Usia & $\mathbf{n}$ & Persentase $(\%)$ \\
\hline 1 & Resiko Rendah & 13 & 43,3 \\
\hline 2 & Resiko Tinggi & 17 & 56,7 \\
\hline & Total & 30 & 100 \\
\hline
\end{tabular}
responden yang memiliki umur resiko rendah 17 orang $(56,7 \%)$ lebih besar dibandingkan 
dengan usia Ibu dengan resiko tinggi sebanyak 31 orang $(43,4 \%)$

4) Paritas

Pada penelitian ini responden paritas dikelompokkan menjadi 2 kategori paritas resiko tinggi (jika Ibu melhirkan $>3$ orang anak, dan paritas rendah ( jika ibu melhirkan $\leq 3$ orang anak. Dapat dilihat pada tabel 4 .

Tabel 4 Distribusi Frekuensi Berdasarkan Paritas di Puskesmas Giri Maya Pangkalpinang Tahun 2017

\begin{tabular}{cccc}
\hline No & Paritas & n & Persentase(\%) \\
\hline 1 & Resiko Rendah & 12 & 40 \\
\hline 2 & Resiko Tinggi & 18 & 60 \\
\hline & Total & 30 & 100 \\
\hline
\end{tabular}

Berdasarkan Tabel 4 diatas bahwa dari 30 respoinden, Ibu yang paritas resiko rendah 18 (60\%) responden lebih besar jika dibandingkan dengan Ibu yang paritas resiko tinggi sebanyak 12 (40\%) responden.

b. Analisis Bivariat

\section{Hubungan Pendidikan dengan Pengetahun Ibu}

Penelitian ini dilakukan pada 30 responden dimana pendidikan dikelompokkan menjadi 2 kategori yaitu rendah dan tinggi Sedangkan pengetahuan dikelompokkan menjadi 2 kategori yaitu kurang dan baik. Hasil uji statistik dapat dilihat pada tabel 5 di bawah ini :

Tabel 5 Hubungan Pendidikan dengan Pengetahuan Ibu tentang Tanda -tanda Bahaya Kehamilan Trimester III

\begin{tabular}{|c|c|c|c|c|c|c|c|}
\hline \multirow{3}{*}{ No } & \multirow{3}{*}{ Pendidikan } & \multicolumn{4}{|c|}{ Pengetahuan } & \multirow{2}{*}{ Jumlah } & \multirow{3}{*}{$\begin{array}{c}P \\
\text { Value }\end{array}$} \\
\hline & & \multicolumn{2}{|c|}{ Kurang } & \multicolumn{2}{|c|}{ Baik } & & \\
\hline & & $\mathbf{F}$ & $\%$ & $\mathbf{F}$ & $\%$ & $\%$ & \\
\hline 1. & Rendah & 8 & 72,7 & 3 & 27,3 & $11 \quad 100$ & \multirow{3}{*}{0,009} \\
\hline 2. & Tinggi & 4 & 21,1 & 15 & 78,9 & 19100 & \\
\hline & Jumlah & 12 & 40 & 18 & 60 & $\begin{array}{ll}30 & 100\end{array}$ & \\
\hline
\end{tabular}

Berdasarkan tabel 5 di atas dapat dilihat bahwa dari 30 responden menunjukkan dari 19 responden yang memiliki pendidikan tinggi dengan pengetahuan baik sebanyak 15 responden $(78,9 \%)$ dan pengetahuan kurang sebanyak (21,1\%). Dari 11 Responden yang memiliki pendidikan rendah dengan pengetahuan kurang sebanyak $8(72,7 \%)$ responden dan pengetahuan baik sebanyak 3 ( 27,3\%) responden. Dari hasil uji statistik Chi-Square didapatkan nilai $p$ value $=0,009 \leq$ dari $\alpha=0,05$ hal ini menunjukkan bahwa ada hubungan yang bermakna antara pendidikan dengan pengetahuan Ibu tentang tanda bahaya kehamilan trimester IIIdi Puskesmas Giri Maya Pangkalpinang Tahun 2017.

\section{Hubungan Usia dengan Pengetahuan Ibu tentang Tanda Bahya Kehamilan}

Penelitian ini dilakukan pada 30 responden dimana Usia dikelompokkan menjadi 2 kategori yaitu usia resiko tinggi dan usia Resiko rendah. Sedangkan Pengetahuan dkelompokkani menjadi 2 kategori yaitu Kurang dan Baik. Hasil uji statistik dapat dilihat pada tabel 6 di bawah ini :

Tabel 6 Hubungan Usia dengan Pengetahuan Ibu tentang Tanda Bahya Kehamilan Trimester III di Puskesmas Giri Maya Pangkalpinang Tahun 2019

\begin{tabular}{|c|c|c|c|c|c|c|c|c|}
\hline \multirow{3}{*}{ No } & \multirow{3}{*}{ Usia } & \multicolumn{4}{|c|}{ Pengetahuan } & \multirow{2}{*}{\multicolumn{2}{|c|}{ Jumlah }} & \multirow{3}{*}{$\begin{array}{c}P \\
\text { Value }\end{array}$} \\
\hline & & \multicolumn{2}{|c|}{ Kurang } & \multicolumn{2}{|c|}{ Baik } & & & \\
\hline & & $\mathbf{F}$ & $\%$ & $\mathbf{F}$ & $\%$ & $\mathbf{N}$ & $\%$ & \\
\hline 1. & Resiko Tin & 9 & 69,2 & 4 & 30,8 & 13 & 100 & 0,013 \\
\hline & Resiko Rendah & 3 & 17,6 & 14 & 82,4 & 17 & 100 & \\
\hline & Jumlah & 12 & 40 & 18 & 60 & 30 & 100 & \\
\hline
\end{tabular}

Berdasarkan tabel 6 di atas dapat dilihat bahwa dari 30 responden dimana 17 responden berusia resiko rendah dengan pengetahuan baik sebanyak $14(82,4 \%)$ dan pengetahuan kurang sebanyak $(17,6 \%)$ responden. Dari 13 responden yang berusia resiko tinggi dengan pengetahuan kurang sebanyak $9(69,2 \%)$ dan pengetahuan baik sebanyak 4 responden $(30,8 \%)$. Dari hasil uji statistik Chi-Square didapatkan $p$ value $=0,013 \leq \alpha=0,05$ hal ini menunjukkan bahwa ada hubungan bermakna antara usia dengan pengetahuan Ibu tentang tanda bahaya kehamilan Trimester III di Puskesmas Giri Maya Pangkalpinang Tahun 2017. 
3. Hubungan antara Paritas dengan Pengetahun Ibu Tentang Tanda Bahaya Kehamilan Trimester III

Penelitian ini dilakukan pada 30 responden dimana paritas dikelompokkan menjadi 2 kategori yaitu paritas resiko tinggi dan paritas Resiko rendah. Sedangkan Pengetahuan dkelompokkan menjadi 2 kategori yaitu Kurang dan Baik. Hasil uji statistik dapat dilihat pada tabel 7 di bawah ini :

$\begin{array}{ll}\text { Tabel } 7 & \text { Hubungan paritas dengan } \\ \text { Pengetahuan Ibu tentang Tanda } \\ \text { Bahya Kehamilan Trimester III } \\ \text { di Puskesmas Giri Maya } \\ \text { Pangkalpinang Tahun 2019 }\end{array}$

\begin{tabular}{|c|c|c|c|c|c|c|c|c|}
\hline \multirow{3}{*}{$\begin{array}{l}\mathbf{N} \\
\mathbf{0}\end{array}$} & \multirow{3}{*}{ Paritas } & \multicolumn{4}{|c|}{ Pengetahuan } & \multirow{2}{*}{\multicolumn{2}{|c|}{ Jumlah }} & \multirow{3}{*}{$\begin{array}{c}P \\
\text { Value }\end{array}$} \\
\hline & & \multicolumn{2}{|c|}{ Kurang } & \multicolumn{2}{|c|}{ Baik } & & & \\
\hline & & $\overline{\mathbf{F}}$ & $\%$ & $\mathbf{F}$ & $\%$ & $\mathbf{N}$ & $\%$ & \\
\hline \multirow[t]{2}{*}{1.} & Resiko & 8 & 66,7 & 4 & 33,3 & 12 & 100 & \multirow{4}{*}{0,024} \\
\hline & Tinggi & & & & & & & \\
\hline \multirow[t]{2}{*}{2.} & $\begin{array}{l}\text { Resiko } \\
\text { Rendah }\end{array}$ & 4 & 22,2 & 14 & 77,8 & 18 & 100 & \\
\hline & Jumlah & 12 & 40 & 18 & 60 & 30 & 100 & \\
\hline
\end{tabular}

Berdasarkan tabel 7 di atas dapat dilihat bahwa dari 30 responden dimana 14 responden paritas resiko rendah dengan pengetahuan baik sebanyak 14 (77,8\%)responden dan pengetahuan kurang sebanyak $4 \quad(22,2 \%)$ responden. Dari 12 responden yang paritas resiko tinggi dengan pengetahuan kurang sebanyak $8(66,7 \%)$ dan pengetahuan baik sebanyak 4 responden $(33,3 \%)$. Dari hasil uji statistik Chi-Square didapatkan $p$ value = $0,024 \leq \alpha=0,05$ hal ini menunjukkan bahwa ada hubungan bermakna antara paritas dengan pengetahuan Ibu tentang tanda bahaya kehamilan Trimester III di Puskesmas Giri Maya Pangkalpinang Tahun 2017.

\section{PEMBAHASAN}

Penelitian ini dilakukan di Puskesmas Giri Maya Pangkalpinang Tahun 2017 dengan menggunkan metode survey analitik dengan pendekatan cross sectional data variabel dependen (Pengetahaun Ibu tentang tanda bahaya kehamilan trimester III) dan variabel Independen (Pendidikan,Usia, Paritas)
Penelitian yang dilakukan menunjukkan Ibu dengan pengetahuan yang baik memiliki persentase $60 \%$ dan Ibu yang memiliki pengetahuan kurang memiliki persentasi $(40 \%)$

\section{a. Pendidikan}

Pada penelitian ini, dari 30 responden ibu hamil dengan pendidikan rendah sebanyak 11 responden ( $36,7 \%$ ) dan $\mathrm{Ibu}$ hamil dengan pendidikan Tinggi sebanyak 19 responden $(63,3 \%)$.

Hasil analisa bivariat didapatkan 19 responden yang memiliki pendidikan tinggi dengan pengetahuan baik sebanyak 15 responden $(78,9 \%)$ dan pengetahuan kurang sebanyak 4 responden $(21,1 \%)$.

Dari 11 responden yang memiliki pendidikan rendah dengan pengetahuan kurang sebanyak 8 responden $(72,7 \%)$ dan pengetahuan baik sebanyak 3 responden $(27,3 \%)$.

Hasil Uji statistik chi square didaptkan $\mathrm{p}$ value $=0,009$. Karena value $(0,009) \leq$ $(0,05)$ berarti ada hubungan bermakna antara pendidikan dengan pengetahuan Ibu tentang tanda bahaya kehamilan trimester III DI Puskesmas Giri Maya Pangkalpinang tahun 2017. Dengan demikian hipotesis yang menyatakan adanya hubungan antara variabel independen dan variabel dependen terbukti secara statistik.

Penelitian ini sesuai dengan teori yang dikemukakan oleh (Notoatmodjo, 2003) Pada umumnya semkin tinggi pendidikan seseorang, semakin baik pula tingkat pengetahuannya sehingga Ibu lebih tahu tentang tanda bahaya kehamilan Trimester III.

Penelitian ini yang sejalan dengan yang dilakukan Ika Desi H (2015) menunjukkan beberapa variabel mempunyai hubungan yang bermakna secara statistik dengan status pendidikan bahwa berdasarkan karakteristik pendidikan, sebagian besar Ibu hamil berpendidikan tinggi sebanyak 30 orang $(60 \%)$ dan sisanya Ibu hamil yang berpendidikan rendah sebanyak 20 orang $(40 \%)$.

Berdasarkan hasil penelitian serta teori ada hubungan yang bermakna antara pendidikan dengan pengetahuan ibu tentang 
tanda bahaya kehamilan trimester III terbukti secara statistik

\section{b. Usia}

Hasil penelitian menunjukkan dari 30 responden ibu hamil yang usia termasuk resiko rendah sebanyak 13 responden $(43,3 \%)$ dan ibu hamil yang usia termasuk dalam resiko tinggi sebanyak 17 responden ( $56,7 \%)$.

Hasil analisa bivariat didaptkan dari 17 responden usia resiko rendah dengan pengetahuan baik sebanyak 14 responeden $(82,4 \%)$ dan dari responden usia resiko rendah dengan pengetahuan yang kurang sebanyak 3 responden $(17,6 \%)$.

Dari hasil 13 responden yang berusia resiko tinggi dengan pengetahuan kurang sebanyak 9 responden $(69,2 \%)$ dan usia resiko tinggi pengetahuan baik sebanyak 4 responden $(30,8 \%)$.

Hasil uji statistik chi square didapatkan $p$ value $=0,013$. Karena value $(0,013) \leq \alpha(00,05)$ berarti ada hubungan bermakna antara usia dengan pengetahuan Ibu tentang bahaya kehamilan Trimester III di Puskesmas Giri Maya Pangkalpinang Tahun 2017.

Penelitian ini sejalan dengan penilitian yang dilakukan oleh Ika Desi H (2015). Berdasarkan karakteristik usia, sebagian besar Ibu hamil memilki usia yang tidak beresiko (20 -35 tahun ) sebanyak 41 orang $(82 \%)$ dan kategori usia beresiko ( $\leq 20$ tahun atau $\geq 35$ tahun), yaitu sebanyak 9 orang $(18 \%)$.

Analisa bivariat menunjukan dari 118 responden kelompok kasus yang mengalami BBLR dengan gizi baik sebanyak 52 responden $(44,1 \%)$ dan yang mengalami BBLR dengan status gizi kurang 66 responden $(55,9 \%)$ sedangkan 118 responden kelompok kontrol yang tidak mengalami BBLR dengan status gizi baik sebanyak 51 responden $(43,2 \%)$, yang tidak mengalami BBLR dengan status gizi kurang 67 responden $(56,8 \%)$.

Penelitian ini sejalan dengan teori yang dikemukakan oleh KKBI (2008), yang menyatkan bahwa umur sangat menentukan suatu kesehatan Ibu. Ibu dikatakan beresiko tinggi apabila Ibu hamil berusia dibawah 20 tahun dan diatas 35 tahun. Umur berguna untuk mengantisipasi diagnosa maslah kesehatan dan tindakan yang dilakukan.

Dari hasil penelitian dapat disimpulkan ada hubungan yang bermakna antara usia dengan pengetahuan ibu tentang tanda bahaya kehamilan trimester III ,terbukti secara statistik.

\section{c. Paritas}

Hasil penelitian dari 30 responden ibu hamil yang termasuk paritas resiko tinggi sebanyak 12 responden $(40 \%)$ dan ibu hamil yang termasuk paritas resiko rendah sebanyak 18 responden (60\%).

Hasil analisa bivariat diketahui bahwa dari 14 responden paritas resiko rendah dengan pengetahuan baik sebanyak 14 responden $(77,8 \%)$ dan paritas resiko rendah pengetahuan kurang sebanyak 4 responden $(22,2 \%)$. Dari 12 responden paritas resiko tinggi dengan pengetahuan kurang sebanyak 8 responden $(66,7 \%)$ dan pengetahuan baik sebanyak 4 responden $(33,3 \%)$.

Dari hasil uji statistik chi square didaptklan $\mathrm{p}$ value $=0,024 \leq \alpha 0,05$ ada hubungan bermakna antara paritas dengan pengetahuan ibu tentang bahaya kehamilan Trimester III di Puskemas Giri Maya Pangkalpinang tahun 2017.

Sejalan dengan teori yang dikemukakan oleh Ramili (2005). Paritas anak kedua dan anak ketiga merupakan paritas yang paling aman ditinjau dari sudut kematian maternal. Pada paritas tinggi lebih dari 3 mempunyai angka kematian maternal lebih tinggi sehingga untuk ibu ibu yang sedang hamil anak ketiga atau lebih dianjurkan untuk lebih intensif dalam pemantauan kesehatan pada saat kehamilan dengan rutin memeriksakan kehamilannya ketenaga kesehatan.

Hasil penelitian ini sejalan dengan penelitian yang dilakukan Ika Desi H (2015). Berdasarkan paritas, sebagian besar Ibu hamil masuk kedalam paritas rendah sebanyak 30 orang $(60 \%)$ dan paritas tinggi sebanyak 20 orang (40\%) memiliki hubungan antara paritas dengan kejadian pengetahuan ibu tentang bahaya kehamilan. 


\section{Maka dapat disimpulkan ada hubungan yang bermakna antara paritas dengan pengetahuan ibu tentang tanda bahaya kehamilan trimester III di Puskesmas Giri Maya Pangkalpinag pada Tahun 2017 secara statistik}

\section{SARAN}

\section{Bagi Puskesmas Giri Maya Pangkalpinang Tahun 2017}

Meningkatkan kualitas asuhan kebidanan yang diberikan kepada Ibu hamil dan diharapkan lebih meningkatkan promosi kesehatan tentang peranan puskesmas di masyarakat guna menurunkan angka kematian Ibu dan Bayi.

\section{Bagi Akbid Bunga Bangsaku Bangka}

Bagi instansi pendidikan diharapkan dapat menambah referensi buku buku kebidanan yang dapat membantu dalam penyusunan penelitian dan diharapkan dapat menjadi bahan bacaan untuk peneliti selanjutnya

\section{Bagi Peneliti yang akan datang}

Bagi penelitian selanjutnya agar dapat meneliti memperluas/memperbanyak variabel-variabel yang lain dengan metode yang berbeda serta sampel yang lebih besar untuk meningkatkan pengetahuan Ibu hamil mengenai kesehatan ibu hamil .

\section{DAFTAR PUSTAKA}

Harnindita, Ika Desi. 2015. Hubungan Usia, pendidikan dan paritas dengan sikap Ibu hamil dalam mengenal tanda - tanda bahaya kehamilan di Puskesmas Piyungan Bantul tahun 2015.http://digilib.unisayogya.ac.id/548/1/ IKA\%20DESI\%20HARNINDITA 20141 0104056_NASKAH\%20PUBLIKASI.pdf

Hidayat,A.A. (2014). Metode Penelitian Keperawatan dan Teknis Analisis Data. Jakarta : Salemba Medika

Kementrian Keseahatan.2016. Diakses 10 september 2018http://www.depkes.go.id

Kusmiyati. 2008. Perawatan Ibu hamil.Fitramaya : Yogyakarta

Lapran tahunan Direktorat Kesehatan Keluarga. Diakses 20 September 2018
Manuaba,IBG. 2010. Ilmu Kebidanan Penyakit Kandungan, dan Keluarga Berencana Untuk Pendidikan Bidan, Jakarta:EGC

Notoatmodjo, S.2012. Metodelogi Penelitian Kesehatan. Jakarta: Rineka cipta

Nugroho,T,dkk. (2014). Buku Ajar Askeb I Kehamilan. Yogyakarta : Nuha Medika

Prawirohardjo, Sarwono. 2014. Ilmu Kebidanan. Jakarta : Yayasan Bina Pustaka Sarwono Prawirohardjo.

Prawirohardjo, Sarwono. 2016. Ilmu Kebidanan . Jakarta : Yayasan Bina Pustaka Sarwono Prawirohardjo.

Profil Kesehatan Prov.Kep.Babel.2015. diakses 15 juni 2018. http://www.depkes.go.id

Ramli.(2005). Pendampingan Perkembangan Anak Usia Dini. Jakarta: Depdiknas.

Worl Health Organization. 2015. Maternal Mortality. Diakses 12 januari 2018.http://www.who.int/mediacentre/fact sheets/fs 348/en. 